\title{
Marteiliosis in mussels: a rare disease?
}

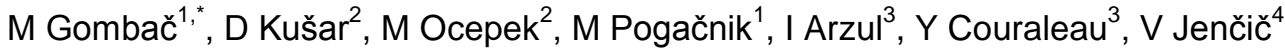

\footnotetext{
${ }^{1}$ Veterinary Faculty, Institute of Pathology, Forensic and Administrative Veterinary Medicine, University of Ljubljana, Ljubljana, Slovenia

${ }^{2}$ Veterinary Faculty, Institute of Microbiology and Parasitology, University of Ljubljana, Ljubljana, Slovenia

${ }^{3}$ Laboratoire de Génétique et Pathologie, Institut Français de Recherche pour I'Exploitation de la Mer

(IFREMER), La Tremblade, France

${ }^{4}$ Veterinary Faculty, Institute of Breeding and Health Care of Wild Animals, Fishes and Bees, University of

Ljubljana, Ljubljana, Slovenia
}

*: Corresponding author : M Gombač, email address : $\underline{\text { mitja.gombac@vf.uni-lj.si }}$

\begin{abstract}
:
Among 1280 cultured and wild adult Mediterranean mussels, Mytilus galloprovincialis, collected over a 1 -year surveillance period from the Slovene Adriatic Sea, $0.3 \%$ were histologically positive for the presence of Marteilia spp. The infection was concentrated in winter. Employing the molecular methods of PCR, cloning, DNA restriction and sequencing, only Marteilia refringens type $M$ was detected in all the infected mussels. Although all life-cycle stages of $M$. refringens severely infected digestive glands, only sporadic disruption of epithelial cells of digestive tubules and focal destruction of digestive tubules were observed in the infected mussels. This was the first detection of $M$. refringens in M. galloprovincialis from the Slovene Adriatic Sea with the lowest prevalence reported to date. In addition, our results highlight the need for sequencing to complement the established PCR-RFLP analysis for correct parasite typing.
\end{abstract}

Keywords: ow prevalence ; Marteilia refringens type $M$; Mediterranean mussels Mytilus galloprovincialis ; Sequencing ; severe infection ; Slovene Adriatic Sea 


\section{Introduction}

Marteiliosis is caused by protozoan parasites of the genus Marteilia, phylum Paramyxea, which encompasses several species, some of them fully characterized like Marteilia refringens (Grizel, Comps, Bonami, Cousserans, Duthoit \& Le Pennec) and Marteilia sydneyi (Perkins \& Wolf) and others only characterized from a morphological point of view including Marteilia christenseni (Comps) and Marteilia lengehi (Comps) (Berthe, Le Roux, Adlard \& Figueras 2004). It has been reported in association with mortalities in European flat oysters, Ostrea edulis (Linné), and mussels Mytilus edulis (Linné) and Mytilus galloprovincialis (Lamarck) (Grizel, Comps, Bonami, Cousserans, Duthoit \& Le Pennec 1974; Villalba, Mourelle, López, Carballal \& Azevedo 1993b; Berthe et al. 2004). In addition, parasites $M$. refringens have been observed in other oyster and mussel species, in cockles and several clam species (Ceschia, Zanchetta, Sello, Montesi, Antonetti \& Figueras 2001; Berthe et al. 2004; López-Flores, Garrido-Ramos, de la Herrán, Ruiz-Rejón, Ruiz-Rejón \& Navas 2008a; López-Flores, Robles, Valencia, Grau, Villalba, de la Herrán, Garrido-Ramos, RuizRejón, Ruiz-Rejón \& Navas 2008b; Pascual, Villalba, Abollo, Garci, González, Nombela, Posada \& Guerra 2010). Infection with $M$. refringens is listed as one of the reportable diseases by the World Organization for Animal Health (OIE).

In Europe, marteiliosis has been described as a disease of flat oysters, O. edulis, Mediterranean mussels, M. galloprovincialis, and blue mussels, M. edulis, caused by $M$. refringens (OIE 2011). The first descriptions of $M$. refringens were recorded in the early 1970s in flat oysters (Grizel et al. 1974). In 1982, Comps, Pichot \& Papagianni discovered a new species of the genus Marteilia, i.e. Marteilia maurini, on the basis of ultrastructural characteristics in Mediterranean mussels from the Venice lagoon. This finding was later contradicted by the fact that these two Marteilia species cannot be differentiated either on the basis of ultrastructural characteristics (Longshaw, Feist, Matthews \& Figueras 2001) nor by $18 \mathrm{~S}$ rRNA gene sequences of Marteilia spp. isolated from oysters and mussels (Berthe, Le Roux, Peyretaillade, Peyret, Rodriguez, Gouy \& Vivares 2000). In further studies targeting the ITS-1 region of the rRNA gene cluster, two genetic types of Marteilia spp., linked to the host species, were confirmed in Europe: $M$. refringens in oysters and $M$. maurini in mussels (Le Roux, Lorenzo, Peyret, Audemard, Figueras, Vivarès, Gouy \& Berthe 2001). However, field studies (López-Flores, de la Herrán, Garrido-Ramos, Navas, Ruiz-Rejón \& Ruiz-Rejón 2004; Novoa, Posada \& Figueras 2005) showed that there is no strict correlation between Marteilia types and host species. Due to the lack of host specificity in addition to high similarity in the IGS region of the parasite genome (López-Flores et al. 2004), M. maurini was considered as a junior synonym of $M$. refringens.

The infection of healthy bivalves occurs when the sea temperature is higher than $17{ }^{\circ} \mathrm{C}$ (Audemard, Barnaud, Collins, Le Roux, Sauriau, Coustau, Blachierd \& Berthe 2001; Carrasco, Arzul, Berthe, Fernandez, Dufort \& Furones 2008). It persists over the year with peaks in prevalence in warm summer months (Villalba et al. 1993b), and is most frequent in the shallow coastal sea (Fuentes, Villalba, Zapata \& Alvarez 1995; Robledo \& Figueras 1995) and in the polluted sea areas (Rayyan, Damianidis, Antoniadou \& Chintiroglou 2006). High salinity inhibits the infection (Ceschia, Mion, Orel \& Giorgetti 1992). In mussels, M. refringens is a potentially lethal pathogen (Villalba, Mourelle, Carballal \& López 1993a); it causes a haemocytic infiltration of epithelial cells and connective tissue of the digestive gland (Villalba, Mourelle, Carballal \& López 1997). Heavy infection results in the massive destruction of digestive gland and death of the host (Figueras, Jardon \& Caldas 1991; Villalba et al. 1997; Rayyan et al. 2006).

The transmission route of infection is still unknown. Direct transmission of $M$. refringens between flat oysters by co-habitation, injection and feeding was unsuccessful (Comps \& Joly 1980; Berthe, Pernas, Zerabib, Haffner, Thébault \& Figueras 1998; Perkins 2005). These 
results suggested the involvement of other species in the transmission of the parasite. In the context of a study carried out in the claire ponds, the copepod Paracartia (Acartia) grani (Sars G.O.) appeared as a potential intermediate host for M. refringens (Audemard et al. 2001; Audemard, Le Roux, Barnaud, Collins, Sautour, Sauriau, De Montaudouin, Coustau, Combes \& Berthe 2002). Subsequent experimental works allowed transmission of the parasite from infected oysters or mussels to $P$. grani, but never succeeded in transmitting the parasite from copepods to naive bivalves (Audemard et al. 2002; Carrasco et al. 2008). By using PCR to screen zooplanktonic samples collected in the Ebre Delta (Catalonia, Spain), Carrasco, López-Flores, Alcaraz, Furones, Berthe \& Arzul 2007 and Carrasco et al. (2008) found several species positive including copepods Paracartia (Acartia) latisetosa (Kritchagin), Acartia discaudata (Giesbrecht), Acartia clause (Giesbrecht), Acartia italica (Steuer), Oithona sp., Euterpina acutifrons (Dana), and larval stages of decapod crustaceans.

The Slovene sea - a part of the Gulf of Trieste, the northernmost end of the Adriatic Sea with its shallowness, constant inflow of fresh water and many other factors highly influencing the temperature, oxygenation and salinity, which vary considerably, represents a specific and rich habitat (Lipej, Orlando-Bonaca \& Makovec 2004; Richter 2005). The health status of cultured and wild Mediterranean mussels in the Slovene Adriatic Sea regarding Marteilia spp. was almost unknown prior to the present study. In 2004, a surveillance system of shellfish farms of Mediterranean mussels, the only shellfish species cultured in the Slovene sea, was established, and 150 cultured Mediterranean mussels were collected annually in late spring and summer and inspected for the presence of Marteilia spp.. To date, all official samples tested negative for the presence of Marteilia spp.. The fact was quite strange, knowing that these protozoa are widespread from the Atlantic to the Persian Gulf (Bower 2011) and were detected also in the northern Adriatic (Ceschia et al. 1992; Zrnčić, Le Roux, Oraić, Šoštarić \& Berthe 2001). To clarify such a phenomenon, we performed a study in which the cultured and wild Mediterranean mussels were monthly collected and inspected for the presence of Marteilia spp., and their dynamics in connection with the sea temperature, oxygenation and salinity was established.

This paper is the first documentation of $M$. refringens infection of $M$. galloprovincialis in the Slovene Adriatic Sea. Prior to this study, all samples that were annually collected in the spring and summer tested negative for the presence of this protozoa.

\section{Materials and methods}

\subsection{Sampling sites and field measurements}

Mediterranean mussels, M. galloprovincialis, were collected from two sites in the Slovene sea: a mussel farm and the natural mussel beds. One sampling per month was performed from November 2007 to October 2008, i.e. 12 samplings from the mussel farm and 11 from the natural beds as the collection of wild mussels proved to be impossible in the month of December due to the stormy sea. From 20 to 40 adult mussels were collected at each sampling, at a depth of approximately three metres. In total, 1280 adult Mediterranean mussels including 960 from a mussel farm and 320 from the natural beds were collected.

Water temperature, oxygenation and salinity were measured at each sampling at the exact point where Mediterranean mussels lived. Water temperature and oxygenation were measured using a thermometer MultiLine P4 - Oxi 320 Set with a dissolved oxygen sensor CellOx 325 (WTW, Germany). Water salinity was measured using a hand-held refract meter S/Mill-E 0-100\%o (ATAGO, Japan). 


\subsection{Laboratory procedures I: sample preparation, macroscopic and microscopic analyses}

Within one hour after collection, live adult mussels were transported to the laboratory in a classic cooling bag. The shell and the flesh of mussels were macroscopically inspected for eventual abnormalities or lesions. A standard section through the visceral mass, including mantle, gill and gonads, was performed. Samples were immediately placed into $10 \%$ formalin solution for not longer than 24 hours at room temperature, and were routinely paraffin embedded. Four $\mu \mathrm{m}$ thick sections were stained with haematoxylin and eosin (HE) and one slide per mussel was examined with a Diastar light microscope (Reichert-Jung, USA) for the presence of Marteilia spp.. HE-stained sections were rated according to the degree of the Marteilia spp. infection, using the Villalba"s et al. (1993b) scale: (i) no infection - no parasites detected, (ii) mild infection - parasites confined to the stomach epithelium, (iii) moderate infection - less than $10 \%$ of digestive tubules infected, and (iv) severe infection - more than $10 \%$ of digestive tubules infected.

Morphometric analyses were performed on tissue slide photographs, using a DS-U2 digital camera (Nikon, Japan) and Microphot FXA microscope (Nikon, Japan). Measurements of the protozoa were performed using the NIS-Elements BR computer program (Nikon, Japan) as follows: the length and the width of 100 randomly selected Marteilia spp. (including different developmental stages) were measured and the average values of measured parameters were calculated.

\subsection{Laboratory procedures II: molecular analyses}

Molecular methods were employed for the species and type determination of Marteilia spp.. Before further processing, paraffin from the tissue sections of the infected mussels was removed by xylene extraction according to the protocol for fixed tissues included in the QIAamp DNA Mini and Blood Mini Handbook (Qiagen, Germany). From the deparaffinised samples, total DNA was extracted using the commercially available QIAamp DNA Mini Kit (Qiagen, Germany) according to the manufacturer"s instructions. Purified DNA, together with type $O$ and type $M$ positive control DNA obtained from the EU Reference Laboratory for Mollusc Diseases (France), was subjected to PCR amplification of M. refringens-specific genomic segments using primers Pr4 and Pr5 targeting the ITS-1 region (Le Roux et al. 2001).

The obtained PCR products were cloned using the TOPO TA Cloning Kit (Invitrogen, USA) according to manufacturer"s recommendations, and positive clones were then selected for plasmid DNA purification by FastPlasmid Mini Kit (Eppendorf, Germany). Twenty clones per PCR-positive mussel were tested again by PCR and subjected to RFLP (restriction fragment length polymorphism) analysis using Hhal (Promega, USA). The selected plasmid DNA suspensions $(n=6)$ were bidirectionally sequenced using the BigDye Sequencing Kit (Applied Biosystems, USA) and Pr4-Pr5 primers. The obtained sequences, of which the three unique ones were deposited in the GenBank database under the accession numbers JQ898012, JQ898013 and JQ898014 (belonging to clones c15, c18 and c19 from mussel $m 1$, respectively), were compared with those included in GenBank using the blast algorithm (Altschul, Madden, Schaffer, Zhang, Zhang, Miller \& Lipman 1997). Some ITS-1 sequences from $M$. refringens were downloaded from GenBank and included in the phylogenetic analysis with sequences obtained in the present study. Sequence alignment was performed using the ClustalX v.2 (Larkin, Blackshields, Brown, Chenna, McGettigan, McWilliam, Valentin, Wallace, Wilm, Lopez, Thompson, Gibson \& Higgins 2007) program with gap opening and gap extension penalties of 15 and 6.66, respectively, and its presentation was adopted from Le Roux et al. (2001). The presence of five unambiguous differences defining the two types $\mathrm{O}$ and $\mathrm{M}$, i.e. at nucleotide positions $323,344,348,349$ and 353 according to 
Le Roux et al. (2001) was manually inspected. A phylogenetic tree was computed using MEGA v.5 software package (Tamura, Peterson, Peterson, Stecher, Nei \& Kumar 2011) with Kimura 2-parameter substitution model (Kimura 1980) and Neighbor-Joining tree reconstruction method (Saitou \& Nei 1987) supported by bootstrap analysis with 1000 resamplings (Felsenstein 1985).

\section{Results}

No abnormal mortality was detected in mussel farms during the one-year sampling period. Neither macroscopic abnormalities nor lesions were detected in the examined mussels. However, four out of 1280 mussels ( $0.3 \%$ prevalence of infection) tested positive for protozoa of the genus Marteilia. In all cases, the infection was severe. All the infected mussels were from mussel farms. M. refringens was detected in January, February, August and December, with $1.25 \%$ prevalence. The severity of infection and the sea temperature, oxygenation and salinity data for the months when positive mussels were collected are shown in Table 1. The average sea temperature varied from $9.1^{\circ} \mathrm{C}$ in winter to $24.1{ }^{\circ} \mathrm{C}$ in summer, the average sea oxygenation from $11.6 \mathrm{mg} \mathrm{L}^{-1}$ in winter to $7.6 \mathrm{mg} \mathrm{L}^{-1}$ in summer and the average salinity from $37.25 \mathrm{~g} \mathrm{~L}^{-1}$ in winter to $38.1 \mathrm{~g} \mathrm{~L}^{-1}$ in summer.

Different life-cycle stages of Marteilia spp. were seen in the epithelial cells of stomach, digestive gland ducts and tubules of all the infected mussels. Early stages (primary and secondary stages), prevailing in the two less severely infected mussels, consisted of spherical to elongated multinucleated cells, up to $12 \mu \mathrm{m}$ in length, predominately nested in the epithelial cells of digestive ducts. In all the infected mussels, numerous pseudoplasmodia (i.e. sporangiosorus or primary cells) from $13.3 \mu \mathrm{m}$ to $21.8 \mu \mathrm{m}$ in diameter, enclosing eight spherical sporonts (i.e. secondary cells) from $4.7 \mu \mathrm{m}$ to $7.2 \mu \mathrm{m}$ in diameter, were seen in the epithelial cells and lumina of digestive gland tubules and ducts (Fig. 1). Each sporont contained two to four round spores (i.e. tertiary cells) from $1 \mu \mathrm{m}$ to $2.1 \mu \mathrm{m}$ in diameter and light refractile inclusion bodies. Some free spores were also seen in the lumina of digestive gland tubules in all the infected mussels.

Sporadically disrupted epithelial cells of digestive tubules and single necrotic digestive tubules were observed in all the infected mussels. In the two less severely infected mussels, a moderate diffuse haemocytic infiltration with focally distributed granulocytomas in digestive gland connective tissue was observed, whereas in the two more severely infected mussels with all the tubules being infected, there were no alterations in connective tissue.

Intracellular ciliates were observed with a prevalence of $24.4 \%$ in the tested mussels, but no ciliates were noticed in mussels infected with $M$. refringens. All histologically detected Marteilia-positive mussels appeared positive by PCR indicating the presence of $M$. refringens. The reaction was weakly positive in the less severely infected mussels (lanes 3 and 4 in Fig. 2) and strongly positive in mussels where all digestive tubules were infected (lanes 1 and 2 in Fig. 2, belonging to mussels $m 1$ and $m 2$ ). For cloning, PCR products from the two more severely infected mussels $m 1$ and $m 2$ were selected and 20 clones per mussel were tested by PCR-RFLP. All the obtained restriction profiles were identical to $M$. refringens type $M$, except one of them which displayed a type $O$ profile (Fig. 3). Six clones were selected for sequencing including the clone which showed a type $O$ restriction profile: clones c18 (JQ898013; clone full name was 11193_2c18), c19 (JQ898014; 11193_2c19) and c20 from $m 1$, and clones $c 21$ and $c 22$ from $m 2$, in addition to clone c15 (JQ898012; 11193_2c15) from $m 1$. Sequences confirmed the PCR-RFLP results. Indeed, five of the obtained sequences showed three Hhal restriction sites (GCGC) at the expected nucleotide positions for $M$. refringens type $M$, while one sequence (clone $c 15$ in Fig. 4, i.e. clone $x$ from Fig. 3 ) showed two Hhal restriction sites at the expected positions for $M$. refringens type $O$ due to a 
deletion at nucleotide position 345 which prevented Hhal digestion at the third GCGC site; clone c15 showed a type "M-like" sequence profile (type M characteristics at 323, 344, 349 and 353 discriminative nucleotide positions and type $\mathrm{O}$ at 348) and differed also at a nondiscriminative position 289 (Fig. 4). However, all the six obtained clone sequences displayed maximum identity (99-100\%) with $M$. refringens type $M$ and more especially with parasites detected in Adriatic Sea (AB513427, DQ426553, DQ426550). The phylogenetic analysis clearly grouped the six sequences including the sequence displaying a type $O$ restriction profile with other $M$. refringens type $M$ sequences (Fig. 5).

\section{Discussion}

The prevalence of infection with $M$. refringens in mussels from the Slovene sea was $0.3 \%$. This is the lowest prevalence of marteiliosis in Mediterranean mussels described to date, as it was reported for the Ebre Delta in Spain to range from $1.67 \%$ to $26.67 \%$ (Carrasco et al. 2007, 2008), for Galicia from 5.5\% to 38.5\% (Robledo \& Figueras 1995), 5\% for Croatia (Zrnčić et al. 2001), 14.6\% (Rayyan et al. 2006) and 21.25\% (Virvilis, Angelidis \& Photis 2003) for Greece, from $16.6 \%$ to $22.2 \%$ for the Adriatic Sea in Italy (Ceschia et al. 1992), $19.3 \%$ for Albania (Pëllumb, Ceschia \& Kapllan 2006), and from $37 \%$ to $70 \%$ for northern Brittany (Auffret \& Poder 1983). However, these differences might be due to the differences in sampling size or period, but on the other hand, transmission of infection among the mussels from the Slovene sea could be restricted.

$M$. refringens was more frequently detected in mussels from the Slovene sea during winter, i.e. in December, January and February, and only once in August. With all the positive cases from our study, free sporangia could be observed in the lumen of digestive tubules. Other authors (Audemard et al. 2001; Carrasco et al. 2008) reported that the infection of healthy bivalves correlated with the sporulation of Marteilia spp., which occurs in spring and summer when the sea temperature is above $17^{\circ} \mathrm{C}$ and decreases in winter when sporangia primordia of $M$. refringens do not develop (Berthe et al. 1998). On the other hand, Carrasco et al. (2007) reported the presence of sporangiosori with mature sporangia in $50 \%$ to $75 \%$ of the infected mussels also in winter with a sea temperature of $8{ }^{\circ} \mathrm{C}$, although mature spores were not released in the lumen of digestive tubules. The reported prevalence was very low and did not exceed the value of $3.34 \%$ reported by Carrasco et al. (2007) for January, which was the lowest prevalence reported to date. Marteilia spp. was detected in Spain from February to October (Carrasco et al. 2008), in Greece from May to November (Photis, KyriaziPapadopoulou, Pneumatikatos, Kaldrymidou \& Kanakoudis 1997), in Croatia in August (Zrnčić et al. 2001) and in Italy in April and from June till September (Ceschia et al. 1992). Ceschia et al. (1992) reported that high salinity also inhibits the infestation. In our study, the infection with Marteilia spp. was detected also in August, when the salinity was high $\left(39 \mathrm{~g} \mathrm{~L}^{-}\right.$ $\left.{ }^{1}\right)$; however, the effect of salinity on marteiliosis should be regarded with care as to date, there have not been many reports regarding its influence on the infection.

Despite the initially apparent discrepancy between PCR-RFLP and sequencing results, we can conclude that all mussels found infected with $M$. refringens from the Slovene sea were only infected with $M$. refringens type $M$. Three polymorphic sites could be observed between the six obtained sequences including a deletion in the Hhal restriction site used to discriminate types $\mathrm{O}$ and $\mathrm{M}$. This result highlights the need of sequencing in addition to RFLP for correct parasite typing.

Based on histological examination, the infection of mussels appeared quite severe, although only sporadically disrupted epithelial cells of digestive tubules and several totally destructed digestive tubules were observed. Similarly, Robledo \& Figueras (1995) observed that the presence of $M$. refringens plasmodia in the epithelial cells of stomach and primary digestive 
tubules did not cause any pathohistological changes, however heavy infection resulted in almost complete destruction of digestive tubules. Likewise, Figueras et al. (1991) and Villalba et al. (1997) reported that heavy infection resulted in massive destruction of digestive gland, which was most extensive during the release of spores from sporangia. In the two less severely infected mussels from our study, a moderate diffuse haemocytic infiltration with focally distributed granulocytomas in digestive gland connective tissue was present. In the two most severely infected mussels, there were no alterations in the connective tissue. Villalba et al. (1993b, 1997) and Carballal, Villalba \& López (1998) discovered that the infection with $M$. refringens in Mediterranean mussels may cause a significant increase of haemocytes in the connective tissue. Occasionally, granulocytomas were also formed and caused the destruction of the parasites and host cells (Villalba et al. 1993b).

In our study, $M$. refringens was detected only in the cultured mussels, which was surprising since mussel seeds, designated for cultivation, were collected from the wild beds in the Slovene sea. In addition, the cultured mussels grow in very similar conditions as the wild ones, including density and sea parameters. We can speculate that the observed phenomenon is possibly a consequence of a very low prevalence, and on the other hand, of the lower number of mussels collected from the natural beds due to the inclement weather conditions in winter, when the infection in mussels mostly occurred. It is also possible that the cultured mussels are more susceptible to the infection due to the reduced host defense caused by certain stressful events, i.e. removal of the mussels from the small socks, their cleaning and redistribution into bigger socks in the middle of the cultivation period. In our study, the observed phenomenon may also be a consequence of the location of mussel farms, which lie in the semi-closed small bays, whereas natural beds are located in more open sea areas. This assumption is in accordance with Robledo \& Figueras (1995) and Fuentes et al. (1995), who found that the infection with Marteilia spp. is more frequent in the shallow sea near the coast. We could not find data in the literature on the prevalence of infection with Marteilia spp. in wild Mediterranean mussels, and to the best of our knowledge, it has never been reported that the cultured mussels are more susceptible to the infection.

Robledo \& Figueras (1995) reported an increase from 8.3 to $29.6 \%$ in the mortality of Mediterranean mussels, which was correlated to the intensity of infection (Villalba et al. 1993b). No abnormal mortality was detected in mussels from the Slovene sea during the sampling period; however, the number of positive samples was too low to enable comparison or further conclusions.

Intracellular ciliates of mussels were also observed in the tested mussels, however there was no cross infection with $M$. refringens (Gombač, Makarovič, Fonda \& Jenčič 2011). We could not find any data in the literature reporting the co-infection with intracellular ciliates of mussels and Marteilia spp..

The involvement of copepods in the life cycle of $M$. refringens could be possible, since A. clausi (Malej 1979; Turk, Bajt, Kovač, Horvat, Milačič, Mozetič, Ramšak, Ščančar \& Malej 2001), A. latisetosa, Oithona sp. and indeterminate harpaticoida, which appeared positive for Marteilia sp. by PCR (Carrasco et al. 2007, 2008), are present in the shallow areas where the mussel farms are located throughout the year (Hure \& Kršinić 1998). These observations questioned the involvement of copepod species and host specificity of $M$. refringens and demonstrate the need of further studies on the parasite life cycle.

To conclude, the infection with $M$. refringens type $M$ in Mediterranean mussels from the Slovene sea is sporadic and the lowest reported to date. Although it is severe, it seems that the impact on the host is minimal and the transmission restricted. The infection is not seasonal, but is concentrated in winter, when sporulation also occurs, at temperatures lower than $10{ }^{\circ} \mathrm{C}$, very high salinity and low oxygenation values. These results suggest that 
changes in the annual surveillance schedule should be taken into consideration for this part of the Adriatic Sea and winter sampling should be included in the surveillance plan.

\section{Acknowledgements}

We are very grateful to Fonda family, especially Dr. Irena Fonda, for their valuable help and the donation of cultured mussels. This research was supported by the Slovenian Research Agency; program P4-0092 (Animal Health, Environment and Food Safety).

\section{References}

Altschul S.F., Madden T.L., Schaffer A.A., Zhang J., Zhang Z., Miller W. \& Lipman D.J. (1997) Gapped BLAST and PSI-BLAST: a new generation of protein data base search programs. Nucleic Acids Research 25, 3389-3402.

Audemard C., Barnaud A., Collins C.M., Le Roux F., Sauriau P.-G., Coustau C., Blachierd P. \& Berthe F.C.J. (2001) Claire ponds as an experimental model for Marteilia refringens life-cycle studies: new perspectives. Journal of Experimental Marine Biology and Ecology 257, 87-108.

Audemard C., Le Roux F., Barnaud A., Collins C., Sautour B., Sauriau P.-G., De Montaudouin X., Coustau C., Combes C. \& Berthe F. (2002) Needle in a haystack: involvement of the copepod Paracartia grani in the life cycle of the oyster pathogen Marteilia refringens. Parasitology 124, 315-323.

Auffret M. \& Poder M. (1983) Studies on Marteilia maurini, parasite of Mytilus edulis from the north coasts of Brittany. Revue des Travaux de I'Institut des Pêches Maritimes 47, 105-109 (in French).

Berthe F.C.J., Pernas M., Zerabib M., Haffner P., Thébault A. \& Figueras A.J. (1998) Experimental transmission of Marteilia refringens with special considerations for its life cycle. Diseases of Aquatic Organisms 34, 135-144.

Berthe F.C.J., Le Roux F., Peyretaillade E., Peyret P., Rodriguez D., Gouy M. \& Vivares C.P. (2000) Phylogenetic analysis of the small subunit ribosomal RNA of Marteilia refringens validates the existence of phylum Paramyxea (Desportes and Perkins, 1990). Journal of Eukaryotic Microbiology 47, 288-293.

Berthe F.C.J., Le Roux F., Adlard R.D. \& Figueras A. (2004) Marteiliosis in molluscs: a review. Aquatic Living Resources 17, 433-448.

Bower S.M. (2011) Synopsis of infectious diseases and parasites of commercially exploited shellfish: Marteilia refringens/maurini of mussels. http://www.pac.dfompo.gc.ca/science/species-especes/shellfish-coquillages/diseasesmaladies/pages/mrmaurmu-eng.htm (Last accessed: 21 December 2012).

Carballal M.J., Villalba A. \& López C. (1998) Seasonal variation and effects of age, food availability, size, gonad development, and parasitism on the hemogram of Mytilus edulis. Journal of Invertebrate Pathology 72, 304-312.

Carrasco N., López-Flores I., Alcaraz M., Furones M.D., Berthe F.C. \& Arzul I. (2007) Dynamics of the parasite Marteilia refringens (Paramyxea) in Mytilus galloprovincialis and zooplankton populations in Alfacs Bay (Catalonia, Spain). Parasitology 134, 15411550. 
Carrasco N., Arzul I., Berthe F., Fernandez M., Dufort M. \& Furones D. (2008) "Delta de l'Ebre" as a natural bay model for Marteilia spp. (Paramyxea) dynamics and life cycle studies. Diseases of Aquatic Organisms 79, 65-73.

Ceschia G., Mion A., Orel G. \& Giorgetti G. (1992) Parasitological survey of the mussel culture of Friuli-Venezia Giulia (North-East Italy). Bollettino Societa Italiana di Patalogia Ittica 9, 24-36 (in Italian).

Ceschia G., Zanchetta S., Sello M., Montesi F., Antonetti P. \& Figueras A. (2001) Presence of parasites in razor clam (Ensis minor and Ensis siliqua) harvested from coastal areas of the southern Tyrrhenian and Adriatic Seas. Bollettino Societa Italiana di Patalogia Ittica 13, 20-27 (in Italian).

Comps M. \& Joly J.-P. (1980) Experimental contamination of Mytilus galloprovincialis Lmk by Marteilia refringens. Science et Pêche 301, 19-21 (in French).

Comps M., Pichot Y. \& Papagianni P. (1982) Research on Marteilia maurini n. sp. parasite of the mussel Mytilus galloprovincialis Lmk. Revue des Travaux de l'Institut des Pêches Maritimes 45, 211-214 (in French).

Felsenstein J. (1985) Confidence limits on phylogenies: an approach using the bootstrap. Evolution 39, 783-791.

Figueras A.J., Jardon C.F. \& Caldas J.R. (1991) Diseases and parasites of rafted mussels (Mytilus galloprovincialis Lmk): preliminary results. Aquaculture 99, 17-33.

Fuentes J., Villalba A., Zapata C. \& Alvarez G. (1995) Effects of stock and culture environment on infections by Marteilia refringens and Mytilicola intestinalis in the mussel Mytilus galloprovincialis cultured in Galicia (NW Spain). Diseases of Aquatic Organisms 21, 221-226.

Gombač M., Makarovič M., Fonda I. \& Jenčič V. (2011) The influence of sea temperature, salinity and oxygenation on intracellular ciliates dynamics in Slovene Mediterranean mussels (Mytilus galloprovincialis). Bulletin of the European Association of Fish Pathologists 31, 66-72.

Grizel H., Comps M., Bonami J.R., Cousserans F., Duthoit J.L. \& Le Pennec M.A. (1974) Research on the agent of the digestive gland disease of Ostrea edulis Linné. Science et Pêche 240, 7-29 (in French).

Hure J. \& Kršinić F. (1998) Planktonic copepods of the Adriatic Sea: spatial and temporal distribution. Natura Croatica 7, 1-135.

Kimura M. (1980) A simple method for estimating evolutionary rate of base substitutions through comparative studies of nucleotide sequences. Journal of Molecular Evolution 16, 111-120.

Larkin M.A., Blackshields G., Brown N.P., Chenna R., McGettigan P.A., McWilliam H., Valentin F., Wallace I.M., Wilm A., Lopez R., Thompson J.D., Gibson T.J. \& Higgins D.G. (2007) Clustal W and Clustal X version 2.0. Bioinformatics 23, 2947-2948.

Le Roux F., Lorenzo G., Peyret P., Audemard C., Figueras A., Vivarès C., Gouy M. \& Berthe F. (2001) Molecular evidence for the existence of two species of Marteilia in Europe. Journal of Eukaryotic Microbiology 48, 449-454.

Lipej L., Orlando-Bonaca M. \& Makovec T. (2004) Raziskovanje biodiverzitete v slovenskem morju (Research on biodiversity in the Slovene sea). National Institute of Biology Marine Biology Station, Piran, Slovenia (in Slovene).

Longshaw M., Feist S.W., Matthews R.A. \& Figueras A. (2001) Ultrastructural characterisation of Marteilia species (Paramyxea) from Ostrea edulis, Mytilus edulis and Mytilus galloprovincialis in Europe. Diseases of Aquatic Organisms 44, 137-142.

López-Flores I., de la Herrán R., Garrido-Ramos M.A., Navas J.I., Ruiz-Rejón C. \& RuizRejón M. (2004) The molecular diagnosis of Marteilia refringens and differentiation between Marteilia strains infecting oysters and mussels based on the rDNA IGS sequence. Parasitology 129, 411-419.

López-Flores I., Garrido-Ramos M.A., de la Herrán R., Ruiz-Rejón C., Ruiz-Rejón M. \& Navas J.I. (2008a) Identification of Marteilia refringens infecting the razor clam Solen 
marginatus by PCR and in situ hybridization. Molecular and Cellular Probes 22, $151-$ 155.

López-Flores I., Robles F., Valencia J.M., Grau A., Villalba A., de la Herrán R., GarridoRamos M.A., Ruiz-Rejón C., Ruiz-Rejón M. \& Navas J.I. (2008b) Detection of Marteilia refringens using nested PCR and in situ hybridisation in Chamelea gallina from the Balearic Islands (Spain). Diseases of Aquatic Organisms 82, 79-87.

Malej A. (1979) The zooplankton of the coastal waters in the Gulf of Trieste. Nova Thalassia 3, 213-231.

Novoa B., Posada D. \& Figueras A. (2005) Polymorphisms in the sequences of Marteilia internal transcribed spacer region of the ribosomal RNA genes (ITS-1) in Spain: genetic types are not related with bivalve hosts. Journal of Fish Diseases 28, 331-338.

OIE (2011) Manual of diagnostic tests for aquatic animals. Chapter 2.4.4. Infection with Marteilia refringens, pp. 331-341. Office International des Epizooties, Paris, France.

Pascual S., Villalba A., Abollo E., Garci M., González A.F., Nombela M., Posada D. \& Guerra A. (2010) The mussel Xenostrobus securis: a well-established alien invader in the Ria de Vigo (Spain, NE Atlantic). Biological Invasions 12, 2091-2103.

Pëllumb A., Ceschia G. \& Kapllan S. (2006) First report of marteiliosis in Mytilus galloprovincialis in Albania. Ittiopatologia 3, 47-52.

Perkins F.O. (2005) Parasite morphology, strategy and evolution. Structure of protistan parasites found in bivalve molluscs. American Fisheries Society Special Publication 18, 93-111.

Photis G., Kyriazi-Papadopoulou A., Pneumatikatos I., Kaldrymidou E. \& Kanakoudis G. (1997) Preliminary study of the protozoan Marteilia sp. as a cause of mussel death (Mytilus galloprovincialis) of the Thermaikos Gulf-Thessaloniki. Bulletin of the Hellenic Veterinary Medical Society 48, 121-125.

Rayyan A., Damianidis P., Antoniadou C. \& Chintiroglou C.C. (2006) Protozoan parasites in cultured mussels Mytilus galloprovincialis in the Thermaikos Gulf (north Aegean Sea, Greece). Diseases of Aquatic Organisms 70, 251-254.

Richter M. (2005) Our sea: the environments and living world of the Gulf of Trieste. Sijart, Piran, Slovenia (in Slovene).

Robledo J.A.F. \& Figueras A. (1995) The effect of culture-site, depth, season, and stock source on the prevalence of Marteilia refringens in cultured mussels (Mytilus galloprovincialis Lmk.) from Galicia, Spain. Journal of Parasitology 82, 354-363.

Saitou N. \& Nei M. (1987) The neighbor-joining method: a new method for reconstructing phylogenetic trees. Molecular Biology and Evolution 4, 406-425.

Tamura K., Peterson D., Peterson N., Stecher G., Nei M. \& Kumar S. (2011) MEGA5: Molecular evolutionary genetics analysis using maximum likelihood, evolutionary distance, and maximum parsimony methods. Molecular Biology and Evolution 28, 2731-2739.

Turk V., Bajt O., Kovač N., Horvat M., Milačič R., Mozetič P., Ramšak A., Ščančar J. \& Malej A. (2001) Raziskave kakovosti morja in kontrola onesnaženja v letu 2001: poročilo za leto 2001 (Research on the sea quality and control of the pollution in 2001: report 2001). National Institute of Biology - Marine Biology Station, Piran, Slovenia (in Slovene).

Villalba A., Mourelle S.G., Carballal M.J. \& López M.C. (1993a) Effects of infection by the protistan parasite Marteilia refringens on the reproduction of cultured mussels Mytilus galloprovincialis in Galicia (NW Spain). Diseases of Aquatic Organisms 17, 205-213.

Villalba A., Mourelle S.G., López M.C., Carballal M.J. \& Azevedo C. (1993b) Marteiliasis affecting cultured mussels Mytilus galloprovincialis of Galicia (NW Spain). I. Aetiology, phases of the infection, and temporal and spatial variability in prevalence. Diseases of Aquatic Organisms 16, 61-72.

Villalba A., Mourelle S.G., Carballal M.J. \& López C. (1997) Symbionts and diseases of farmed mussels Mytilus galloprovincialis throughout the culture process in the Rías of Galicia (NW Spain). Diseases of Aquatic Organisms 31, 127-139. 
Virvilis C., Angelidis P. \& Photis G. (2003) Presence of the parasite Marteilia sp. in the shellfish of the Thermaikos Gulf in northern Greece. Bulletin of the European Association of Fish Pathologists 23, 157-161.

Zrnčić S., Le Roux F., Oraić D., Šoštarić B. \& Berthe F.C.J. (2001) First record of Marteillia $\mathrm{sp}$. in mussels Mytilus galloprovincialis in Croatia. Diseases of Aquatic Organisms 44, 143-148.

\section{Tables}

Table 1 Temperature $(T)$, oxygenation $(O)$ and salinity $(S)$ of the sea in the months when Marteilia refringens was detected in mussels

\begin{tabular}{|c|c|c|c|c|c|}
\hline \multicolumn{2}{|c|}{ M. refringens-positive samples } & \multirow{2}{*}{ Month } & \multirow{2}{*}{$\mathrm{T}\left[{ }^{\circ} \mathrm{C}\right]$} & \multirow{2}{*}{$\mathrm{O}\left[\mathrm{mg} \mathrm{L}^{-1}\right]$} & \multirow{2}{*}{$S\left[g L^{-1}\right]$} \\
\hline number & degree of infection & & & & \\
\hline 1 & all tubules infected & January & 9 & 10.3 & 38 \\
\hline 1 & $\leq 90 \%$ of tubules infected & February & 9.2 & 10.05 & 37 \\
\hline 1 & all tubules infected & August & 22.2 & 7 & 39 \\
\hline 1 & approx. $10 \%$ of tubules infected & December & 10.7 & 10.64 & 39 \\
\hline
\end{tabular}

\section{Figures}

Figure 1 Light micrograph of a HE-stained section under 400× magnification showing Marteilia refringens type $M$ in digestive gland of two Mytilus galloprovincialis collected from the Slovene Adriatic Sea; scale bar represents $20 \mu \mathrm{m}$.
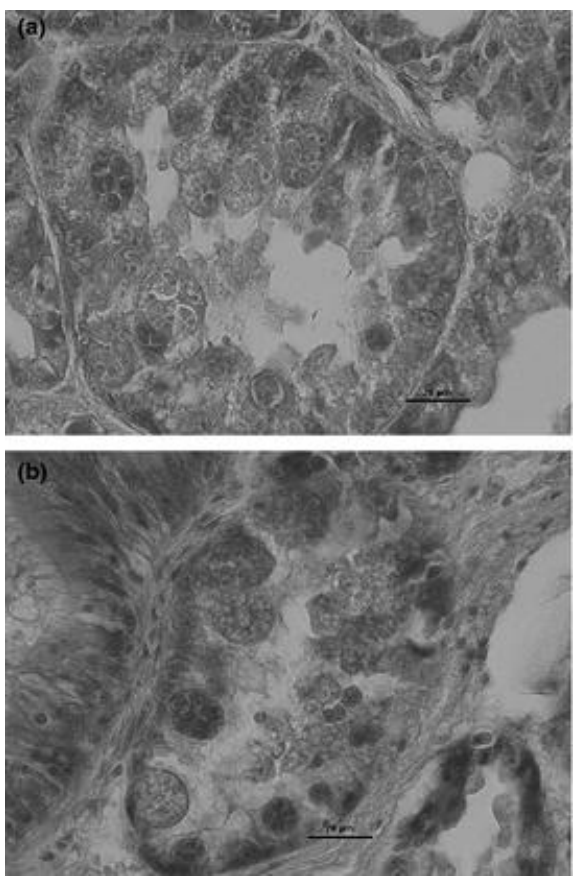
Figure 2 PCR amplification of Marteilia refringens-specific genomic segments using Pr4-Pr5 primers (Le Roux et al. 2001). Lanes 1-4: Marteilia-positive mussels from the present study (1-2: heavily infected mussels $m 1$ and $m 2,3-4$ : less severely infected mussels), Lanes 5-8: positive controls (5-6: heavily infected mussels, 7-8: type $O$ and $M$ positive control DNA), Lanes 9-10: negative controls, Lane L: SimplyLoad 100 bp DNA Ladder (Lonza, Switzerland).

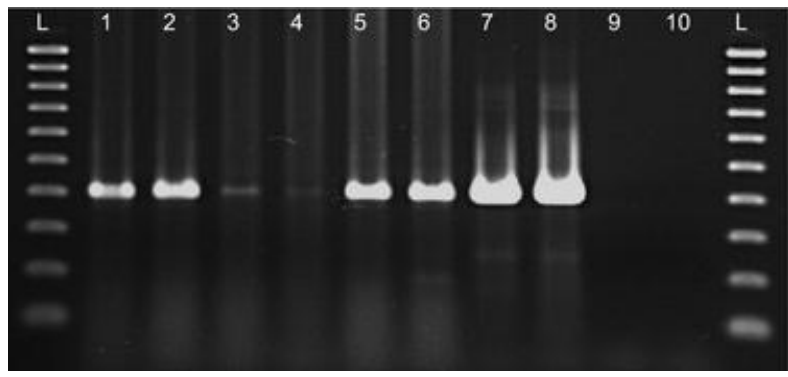

Figure 3 Restriction profiles obtained after Hhal digestion of Pr4-Pr5 PCR products from one mussel ( $(m 1)$ found heavily infected with Marteilia refringens; 19 tested clones showed a type $\mathrm{M}$ profile and one clone $(\mathrm{x})$ a type $\mathrm{O}$ profile. Lane $\mathrm{n}$ : negative control, Lanes $\mathrm{O}$ and $\mathrm{M}$ : two positive controls corresponding to $M$. refringens type $O$ and $M$ respectively, Lane $L$ : SmartLadder SF (Eurogentec, Belgium).

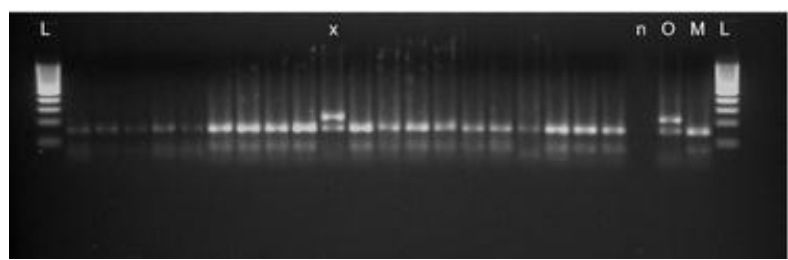


Figure 4 Alignment of sequences obtained in the present study and some ITS-1 Marteilia refringens sequences available at GenBank, including the sequences of parasites detected in Adriatic Sea (AB513427, DQ426553, DQ426550). Hhal restriction sites (GCGC) used to discriminate $M$. refringens types $O$ and $M$ are marked with grey. Presentation of alignment is adopted from Le Roux et al. (2001) with the five discriminative differences at nucleotide positions 323, 344, 348, 349 and 353. Five of our sequences (sequences of clones c18, c19, c20, c21 and c22), DQ426605, DQ426599, AJ629340, AB513427, DQ426553 and DQ426550 show a type M profile, while sequences DQ426595, DQ426626, AJ629337 and DQ426583 a type O profile. Sequence of clone c15 shows a type „M-like" profile (type M at $323,344,349$ and 353 , and type $\mathrm{O}$ at 348); in addition, it has a substitution at 289 and a deletion at 345 .
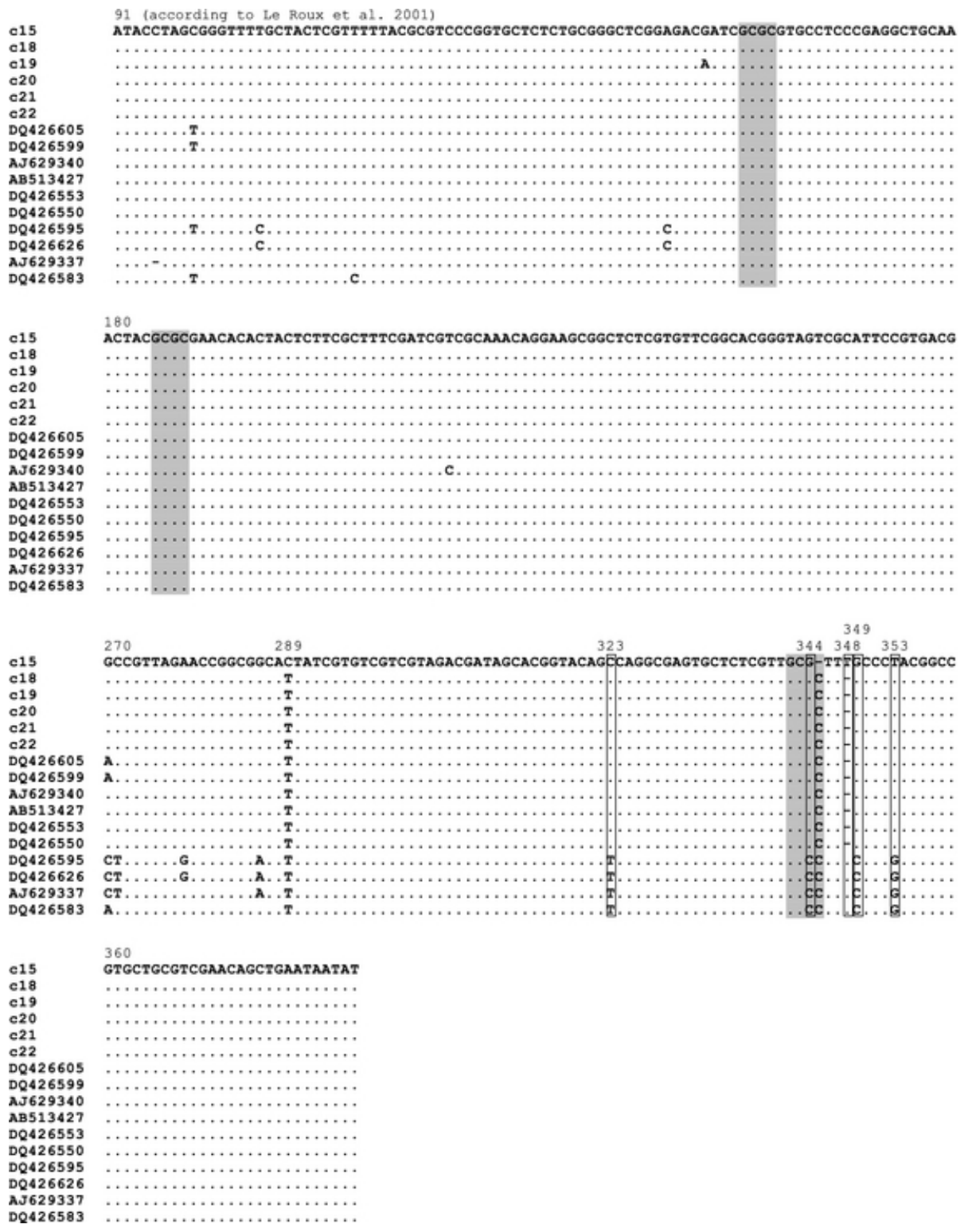
Figure 5 Neighbor-Joining analysis including 294 positions corresponding to the six sequences obtained in the present study (c15, c18, c19, c20, c21 and c22), six Marteilia refringens type $M$ sequences (DQ426605, DQ426599, AJ629340, AB513427, DQ426553 and DQ426550) and four M. refringens type O sequences (DQ426595, DQ426626, AJ629337 and DQ426583). Numbers at branch nodes indicate bootstrap confidence values in percent (based on 1000 replicates).

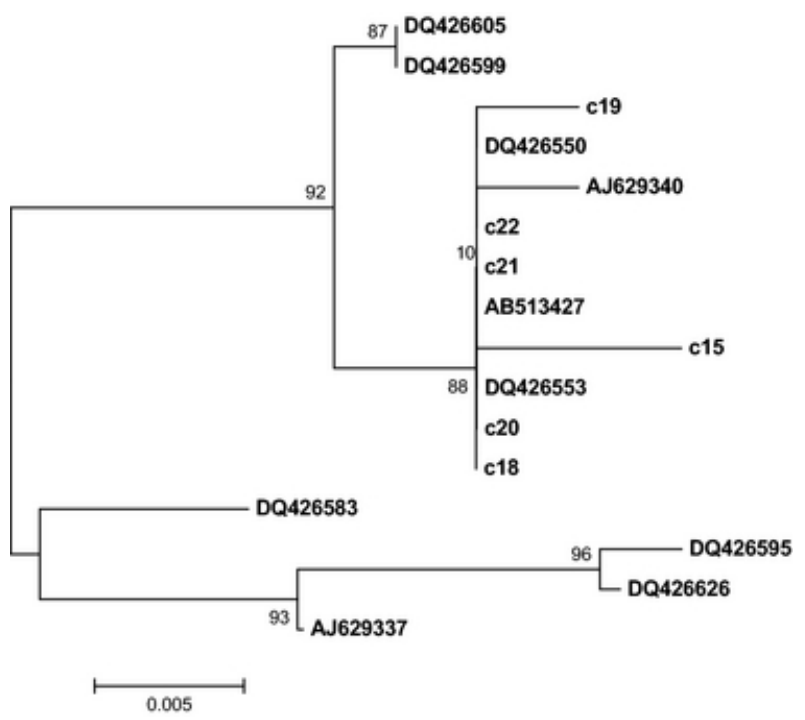

